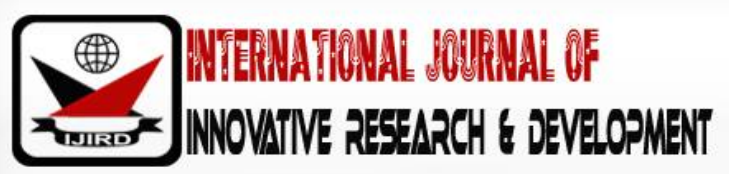

ISSN 2278 - 0211 (Online)

\section{Politics of Oil De-regulation and Nigeria's Change Agenda}

\section{Anas Sani Anka \\ Assistant Lecturer, Department of History \& International Studies, Federal University Gusau, Nigeria}

\begin{abstract}
:
This position paper examines the politics of oil deregulation and its connection with the President Buhari's change agenda. The paper equally make a critical review of the history of oil discovery in Nigeria and its impacts in changing the economic perspective of Nigeria specifically how oil discovery influenced greater shift by making Nigeria moved from Agro-based to oil relying economy. The paper also make a comparative analysis between subsidy and deregulation regimes and make an assessment of the major crises that characterized the subsidy regime especially corruption and lack of accountability in the revenue generated through the sales of the nation's crude oil for over five decades. The paper also make an analysis of what the APC Change agenda is all about and its connection with the deregulation of the downstream oil sector in Nigeria.
\end{abstract}

\section{Introduction}

One of the critical decision taken by the Present administration of Muhammadu Buharisince its inauguration in May 29th 2015 is, "deregulation of the downstream oil sector" which formally marked the beginning of the withdrawal of the government continued payment of the Subsidy to the Nigeria's oil importers. The decision saw the rapid increase in the official pump price of petroleum from eighty six naira(N86) to one hundred and forty five naira (N145) per liter. The argument of the Federal government is that, an average of one trillion naira per year is paid as fuel subsidy in the last five years despites mounting debts and infrastructural deficit (Ejoh, 2016). This amount of money being paid by the Nigerian government as "Subsidy Intervention" does not normally reduced any pain to an ordinary Nigerian, as the huge amount spent for the subsidy payment normally ended up in the hand of few individuals that have no connection with the supply of the petroleum product in to the country. As argued by (Adeleye 2015), the question of subsidy payment has given room to suspicion of corruption in many places since it has been discovered that, ghost marketers appeared in the list of importers.

Various corruption cases have been associated with the subsidy regime in Nigeria. Poor management of petroleum resources has led to the socio-economic and political complex interaction problems involving the people, economic development and environment. Despite massive influx of oil revenues, Nigeria seems to suffer from the "Oil Curse" or the "Natural Resource Curse" due to poor governance and lack of effective environmental and sustainable awareness (Aniefiok 2013) as cited by (Gbadegbo 2008). In a mid-2015 for instance, the Nigerian Extractive Transparency Initiative (NEITI) released its audit report indicating that, the Federal Government spent about N4.5 trillion naira between 2006 and 2012 within a period of seven years as subsidy on petroleum products imported to the country.

To manage these unresolved corruption cases in the Nigeria's oil sector, successive administrations have made attempt to deregulate the downstream sector of the oil but, the decisions have been confronted with series of resistance including street protests by the members of the organized labour, Civil Society Organizations as well as religious groups. Oil Deregulation simply means reduction or elimination of government control or regulation in a particular industry usually enacted to create more competition within the industry (Olalekan 2016). The decision to de-regulate the Nigeria's downstream oil sector may not be un-connected with the fulfillment of President MohdBuhari strategy of reviving the nation's economy through privatization, competition, and diversification as contained in his message of "Change Agenda". The change agenda which is the slogan of the APC's led administration under Buhari streamlined series of transformational initiatives that would help change Nigeria and one of those sectors promised to be transformed is the "Oil Sector". President MohdBuhari was once quoted during a campaign in 2015 that, "I am committed to transforming Nigeria to a country where entrepreneurship thrives, enterprises flourishes and the government get out of your way so that you can create value, build the economy and aggressively expand wealth" (The Nation 2015).

The objective of this position paper is to examine the discovery of oil and its contribution to the development of the Nigerian economy since 1970s. It equally analyzes the extent of the impacts of corruption in the Nigerian downstream oil sector through the subsidy intervention and the recent steps taken by the federal government to withdraw the payment of subsidy and how that decision can help change the situation for the betterment of the Nigerian citizens in the long run. 


\section{0il and Nigerian Economy}

Nigeria is blessed with vast quantity of oil and is the sixth largest oil exporter in the OPEC. This has helped the country generated millions of Dollars in revenues over the last forty years since oil was found in Nigeria (Ifiok 2012). The history of oil discovery in Nigeria could be traced to one of the economically potential region in the country "Niger Delta" in the present day South-South region. Niger Delta is situated at the apex of the gulf of the guinea on the west coast of the Africa and on the SouthSouth geo-political zone. (Anifiok, 2013) argued that, Niger Delta which is a home to some 31 Million people occupies a total area of about 75,000 Kilometers and make up 75\% of Nigeria's land mass. The region has nine oil producing states which are: (Abia, Akwa-Ibom, Bayelsa, Cross-River, Delta, Edo, Ondo, Imo and Rivers with an estimated one hundred and eighty five Local government area councils.

Though there are conflicting accounts as regards to where oil was first discovered in Nigeria, the most popular historical theory as regard to the origin of oil discovery in Nigeria is that, oil was first discovered in Nigeria at Oloibiri. In the Niger Delta region of Nigeria (Gbagdegbo, 2008) argued that, Oil was discovered in Nigeria in 1956 at Oloibiri in the Niger Delta after half a century of exploration. The discovery was made by Shell BP at the time the sole concessionaire. In his paper "Crude Oil and British Imperialism in Nigeria 1903-1956" Ibrahim Khalid Abdulsalam wrote that, "the age of petroleum began in 1859 with the discovery of crude oil by Colonel Edwin Drake in Pensylvania United States". He added that, Drake made this accidental discovery when he drilled brine with the purpose of getting underground deposit of brine in order to extract salt but to his surprise after a few hundred feet underground black liquid began to gush out in to the air. Soon after his discovery scientists found out that, after the crude oil is processed it could be used as a fuel for heating and lightening and for providing mechanical power (Onyedi, 2013)

There is also another historical account which provides that, the development of the oil minerals activities that is exploration of oil and gas in Nigeria followed this initial geological survey when the German Nigerian Bitumen Corporation discovered crude oil in the water side of Okitipupa about hundred kilometers east of Lagos in 1908 but the activities of these companies where short-lived as its pioneer efforts were halted by the World Wars as the German interest could not continue in Nigeria being British protectorate. These, plus many more historical accounts on the origin of oil in Nigeria remain unresolved among the scholars.

Before the oil discovery, Nigeria still maintained a fairly better and performing economy with agriculture dominating almost up to seventy percent of the nation's foreign exchange. During the 1964-1965, agriculture accounted for fifty five percent of GDP and employed seventy percent of the adult workforce in Nigeria (Malton 1981) as cited by ((Sekumade, 2009). In another account (Ekundare 1978) argued, Agricultural export crops like cocoa, groundnut, cotton, rubber, palm oil, palm kanel, etc. account for an average of between sixty-five to seventy five percent of Nigeria's foreign exchange earnings and provides the most important source of revenue for the federal as well as state governments through exports products and sales taxes.

After the Oil discovery however, things began to take a new shape as the attention of the government and the people of Nigeria turns to access to the oil wealth. As argued by (Sekumade, 2009), three years after an oil boom followed and the country was awash with money, indeed there was money for almost all the items in its development plans. The oil sector began to play a vital role in shaping the Nigerian economy and its political destiny in the early sixties when Nigeria becomes an independent state on the $1^{\text {st }}$ of October 1960. (Aniefiok, 2013) argued, following the increase dominance of the Nigerian economy by the petroleum sector, the sole concession policy was abandoned and exclusive exploration right was introduced to encourage other Multi-National Companies aimed at accelerating petroleum exploration production. Moving to the next steps he argued, Federal government of Nigeria started its Department of Petroleum Resources (DPR) Inspectorate in 1970 and Nigeria joined the Organization of Petroleum Exporting countries (OPEC) in 1971. The First National Oil Company, the Nigerian National Oil Corporation (NNOC) was created in 1971 and its Nigerian National Corporation in 1977 in order to take control of the country's petroleum industry.

From that period of the structural formation in the Nigeria's oil sector, Oil continue to dominate the most significant aspect of the Nigeria's economic development both at home and abroad. (Aniefiok, 2013) argued, Crude Oil sales income as a proportion of foreign exchange earnings escalated from $2.5 \%$ to $58.1 \%$ in 1970 to $93.6 \%$ in 1975 greater than $98 \%$ through the 1st half of the 1980's. Production of Oil and Gas resources have been ongoing for the past five decades and it account for over 85\% of the Nigeria's Gross Domestic Products (GDP) representing over 95\% of the nation's foreign exchange revenue and contributes over $80 \%$ of the government revenues. The overall oil and gas production from the Niger-Delta region by the Nigerian government and Multi-National Oil Companies as cited by (Aniefiok, 2013) has generated an estimated $\$ 600$ billion since 1960s.

\section{Petroleum Subsidy Regime in Nigeria and its Controversies}

Petroleum Subsidy usually starts as an attempt to avoid inflation and shield citizens from the pain of price increases in global energy market (Brendan. 2014). In another definition, Petroleum Subsidy means a system through which the government cushions the effects of high oil prices at the International market, where by the government bears the burden of the differences between the landing cost of the refined product and pump prices in the local markets (Micheal. 2014). The history of petroleum subsidy in Nigeria could be traced to the early seventies when the Northern Political elites pressurized the government to declared the regime of "Uniform Pump Price" in order to create a level playing ground between the 
Southern part which are the oil producing states and the Northern parts of the country where oil is not been produced. (Adeleye. 2015) argued, many Northerners in the 1970s thought that "Uniform Prices" of petroleum products throughout the country would ensure even economic development and quality of public and general welfare. The Northern political elites unfortunately won the battle by pressurizing the government to declare regime through a Decree of 1975 which was amended by the Decree 32 of 1982. (Adeleye, 2015) identified the roles of the government as provided for in the Decree to include among others: be responsible for fixing prices of the main products- petrol, diesel, and kerosene and also for their supply. To ensure the smooth working of the system, the NNPC built deports with storage tanks in many places from where marketers lifted (bought) the products. The financial aspect of the scheme under the decree was left to the Petroleum Equalization Fund (PEF) to sort out arrangement of re-imbursement were made to oil companies which incurred losses by selling at the "Uniform Prices" that appears as the origin of the subsidy. From 1978 to date Nigerians were forced to purchase petroleum at different prices as highlighted by (Ejoh. 2016).

\begin{tabular}{|c|c|c|}
\hline S/ NO & Years & Pump Prices \\
\hline 1 & $1978-1990$ & $10-15$ Kobo \\
2 & $1990-1992$ & 60 Kobo \\
3 & 1992 & 70 Kobo \\
4 & 1993 & 3.25 Naira \\
5 & $1994-1999$ & 11 Naira \\
6 & 1999 & 20 Naira \\
7 & 2000 & 22 Naira \\
8 & $2001-2003$ & 26 Naira \\
9 & $2003-2007$ & 40 Naira \\
10 & $2007-2009$ & $70-100$ Naira \\
11 & $2012-2015$ & $97-100-67$ Naira \\
12 & 2016 & $86-145$ Naira \\
\hline
\end{tabular}

Table 1: Prices of Petroleum Per Liter

Source: Adeleye A. (2016)

One of the most controversial components of the subsidy regime that generated unending debate among Nigerians is the Corruption that bedeviled the entire process. Many theories have been constructed as to the reasons why subsidy regime has to be brought to an end in Nigeria. Corruption according to the Transparency International corrodes the fabric of society; it undermines people's trust in political and economic system, institutions and leaders. It can cost people their freedom, health, money and sometimes their lives. (Micheal. 2014) argued, fuel subsidy regime in Nigeria has since 2012 been fraught with controversies such that many believe is capable of crippling the Nigerian economy if not properly handled. The issue took a worrisome dimension when it was realized that, between 2006 and 2013 Nigeria had spent over 5.4 Trillion Naira subsidizing petroleum. This does not include amount expended on kerosene subsidy. The amount spent on petroleum subsidy alone in eight years is 15.57\% higher than the 4.69 Trillion Naira 2014 National budget and also 10.61\% more than the 2013 budget of 4.93 Trillion Naira. In another perspectives, the amount the country is spending on subsidy is almost twice the amount (196.07\%) allocation for education in the 2014 budget which is 495.28 Billion Naira more than three times (369.6\%), the 655.47 Billion Naira allocated for the Universal Basic Education Commission and Tertiary Education Trust Fund (TETFUND). (Brendan G. 2014) argued that, energy subsidies are expensive, they eat up national budget. Benefits end up going mostly to the richest citizens and crowd out more productive government spending on education or infrastructures and reduce energy efficiency.

Nigerians are however, not much concern about how huge the figures allocated for the petroleum subsidy stands but, what impacts does the intervention made to the ordinary citizen who is the principal target of the scheme. Many literatures have argued that, corruption in the name of subsidy has done more harm than good to the economy of the country, (Olufemi 2015), argued, Nigeria would have been buoyant enough to finance its 2015 budget of 4.36 Trillion Naira and still pay off its external debt of 2.08 Trillion Naira if it had not lost more than that amount \$326 Billion (\#6.4 Trillion) to massive corruption that characterized oil sales by the Nigerian petroleum Corporation. In one of the corruption case involving Nigerian National Petroleum Corporation (NNPC) and a foreign oil company Halliburton, prominent Nigerians are finger-pointed as highlighted below: 


\begin{tabular}{|c|c|c|c|}
\hline S/ No. & Years & Name of Individuals & Amount \\
\hline 1 & $1994-1995$ & Gen. Sani Abacha Former Military Dictator & $\$ 40$ Million \\
2 & $1996-1998$ & Dan Etete Former Minister of Petroleum under Gen. Abacha & $\$ 2.5$ Million \\
3 & $1996-1998$ & M. D. Yusuf Former Inspector General of Police & $\$ 75,000$ \\
4 & 1998 & Gen. Sani Abacha's Brother, Abdullahi Abacha & $\$ 1.887$ Million \\
5 & $1999-2000$ & Atiku Abubakar 1999-2007 \& Dan Etete & $\$ 37.5$ Million \\
6 & $2001-2002$ & Obasanjo \& Atiku Abubakar and Funsho Kupolokun & $\$ 74$ Million \\
7 & $2001-2002$ & Mohd Gidado Bakare a Retired Chief Planning Officer & $\$ 3,108,675$ \\
8 & $2001-2002$ & Bodunde Adeyagun Ex-Personal Assistant to Obasanjo & $\$ 5$ Million \\
9 & $2001-2002$ & Ibrahim Aliyu a Retired Federal Permanent Secretary & $\$ 11.7$ Million \\
10 & March 1999 & Nasiru Ado Bayero Son of the Emir of Kano & $\$ 600,000$ \\
11 & $1999-2000$ & Shinkafi and Glosmer International & $\$ 195,000$ \\
12 & March 1999 & Edith Edeghoughou & $\$ 290,000$ \\
13 & March 1999 & Zertasha Malik \&Greaty Oversea & $\$ 600,000$ \\
\hline
\end{tabular}

Table 2: Nigeria's Halliburton Scandal

Source: The Nation 2016

Independent investigative analysis by the Natural Gas Governance Institute (NRGI) has revealed that, over \$32 Billion oil revenue was lost to the Nigerian National Petroleum Corporation's mismanagement of domestic crude allocation (DCA). (Olufemi. 2015) argued further, National Oil Company's discretionary spending from domestic crude oil sales revenue has skyrocketed, exceeding \$65 billion a year for the 2011 to 2013 period (over $\$ 18$ billion in three years). The in-depth research found no evidence that NNPC between 2004 and 2014 forwarded to the treasury any revenue from sales of Okono crude with volumes of over one hundred million barrels with an estimated value of $\$ 12.3$ Billion dollars.

Nigeria is ranked among the most corrupt nations where public funds especially revenue from the sales of crude oil remains unaccountable. (Donwa, Bame and Ogbude. 2015) presented the IMF graphic ranking of Nigeria in terms of corruption from 1996-2010 as follows:

\begin{tabular}{|c|c|c|}
\hline Years & Ranking & No: of Countries \\
\hline 1996 & $54^{\text {th }}$ & 54 \\
1997 & $52^{\text {nd }}$ & 52 \\
1998 & $81^{\text {st }}$ & 85 \\
1999 & $98^{\text {th }}$ & 99 \\
2000 & $90^{\text {th }}$ & 90 \\
2001 & $90^{\text {th }}$ & 91 \\
2002 & 101 th & 102 \\
2003 & $132^{\text {nd }}$ & 133 \\
2004 & $144^{\text {th }}$ & 146 \\
2005 & $152^{\text {nd }}$ & 159 \\
2006 & $142^{\text {nd }}$ & 163 \\
2007 & $147^{\text {th }}$ & 180 \\
2008 & 121 nd & 180 \\
2009 & $130^{\text {th }}$ & 180 \\
2010 & 134 th & 178 \\
\hline
\end{tabular}

Table 3: International Monetary Fund Corruption Survey on Nigeria Source: Donwa, Bame and Ogbude (2015)

Not until in 2016, the nation's refineries remain at comatose with almost up to seventy percent of the nation's domestic fuel consumption coming from the major oil importers.(Gbadegbo. 2008) argued, the combine capacities of these refineries exceed the domestic consumption of refined product chief of which is Premium Sprit (Gasoline) whose demand is estimated at thirty three million liters daily. These refineries are however operating per below installed capacities as they were more or less abandoned during the military era skipping the routine and mandatory turn around maintenance that made products importation inevitable. The popular argument on the mismanagement of the Nigeria's fuel subsidy funds is that, the over four trillion naira spent as subsidy intervention by the Federal Government could have been used in reviving the government's own refineries and make them functional ever than before.

\section{The New Regime of Deregulation}

With an estimated 37.2 Billion barrels of proven oil reserves. Nigeria is one of the world's largest oil producers however; the country's mineral riches have not resulted in a significant improvement in the quality of life for majority of 
Nigeria's citizens (Nelipher and Vera. 2012). Nigerian government under Muhammadu Buhari has decided to suspend the payment of the subsidy intervention as part of the economic measures aimed at managing the rampant corruption cases in the Nigeria's downstream oil sector. Beyond the cases of corruption, there are other challenges facing the oil industry which necessitated the government to taking such a decision they include: public control and bureaucracy in the oil industry, poor funding and investment, communal disturbances, smuggling and diversion of petroleum products, fraudulent domestic marketing pricing, products adulteration, relatively low level of investment in the sector compared to its potentials, high technical cost of production due to low level of technological development, restrictions imposed by crisis and production, disruptions caused by host communities and environmental degradation (Isiak. 2016).

In an address to the people of the country Nigeria's Vice President Yemi Osibanjo denied the insinuation that, the decision taken by their administration is the final move toward formalizing deregulation of the downstream oil sector in Nigeria arguing that, it was purely a decision aimed at responding to the foreign exchange problem in the face of the dwindling crisis in the International Oil Market. "Our local consumption of fuel is almost entirely imported. The NNPC exchanges crude from its joint ventures share to provide about $50 \%$ of local fuel consumption. The remaining $50 \%$ is imported by major and independent marketers (Isiak. 2016). To further buttress the position of the government, Osibanjo added "marketers until three months ago sourced their foreign exchange from the Central Bank of Nigeria at official rates. However, since last year, independent marketers have brought in little or no fuel because they are un-able to get foreign exchange from the Central Bank of Nigeria" (Isiak. 2016). In an independent argument to support Nigeria's decision for petroleum deregulation, Global Petroleum Industry made a review of the pump prices in some selected states in the African continent and come up with the following findings:

\begin{tabular}{|c|c|c|c|}
\hline S/ No & Countries & \$ Cost Per Liter & NCost Per Liter \\
\hline 1 & Nigeria & 0.72 & 145 \\
2 & Togo & 0.8 & 159.2 \\
3 & Ghana & 0.93 & 185 \\
4 & Cameroun & 11 & 218.9 \\
5 & Niger & 6.9 & 179.1 \\
6 & Mali & 1.15 & 228.85 \\
7 & Guinea & 1.17 & 232.83 \\
8 & Gabon & 0.85 & 169.15 \\
9 & Sierra Leon & 0.94 & 187.06 \\
10 & Ivory Coast & 0.97 & 193.03 \\
11 & Gambia & 1.25 & 248.75 \\
12 & Burkina Faso & 1.25 & 248.75 \\
13 & Mauritania & 1.28 & 256.71 \\
14 & Senegal & 1.18 & 234.82 \\
\hline
\end{tabular}

Table 4: Pump Prices across Africa

Source; Global Petroleum Price.com

But critics take it up with the Nigerian government especially on the need for it to clearly define measures that would help cushion the effects of the hardship the decision will bring to the common man in Nigeria. (Kperogi. 2015) argued, it is simply unconscionable and immoral that Americans should pay less for petroleum than Nigerians especially given that, the minimum wage in Nigeria is measly eighteen thousand naira monthly, which is not even paid regularly in most states. Eighteen thousand naira is the equivalent of $\$ 90$ if you use the official exchange rate of $\mathrm{N199}$ to a dollar. The minimum wage in America is \$1,160 a month which is equivalent to N231, 000 again using the official exchange rate. "Any "deregulation" or "Subsidy" that ask a person who earns N 18,000 to pay more for petroleum than a person who earns N231,000 is conscienceless and indispensible. It is death sentence by installment" (Kperogi. 2016).

Again, others are of the view that, it is wrong for the government to indirectly maintained a stake in determining how much a liter of petroleum should be sold to the citizens. This is because it would be for the interest of the free market economy if the oil importers who received no single intervention from the government are allow to determine how much they can afford to import the product and at which price they can disposed it to the local consumers. (Kurfi. 2016) argued, if the government really wants to ensure stability in the Nigerian oil through the deregulation process, it should allow the oil marketers to freely drive the downstream sector of the oil industry, import as much oil as they can at a price convenient for them and sales it at a competitive price to the Nigeria's local consumers.

Another side of the argument is, the non-privatization of the government owned refineries which experts says, supposed to be the final steps of the deregulation. (Kurfi. 2016), argued that, while the government withdraw from regulating the downstream oil sector, all its refineries are supposed to be disposed because, in a normal deregulated economy, whether government like it or not some oil marketers in the nearest future are going to build refineries to strengthen their economic base in the country instead of importing refined product at a high cost This is because, they wants to minimize the cost of transporting the refined product as well as maximizes profits. 


\section{Deregulation and its connection with the Nigeria's Change Agenda}

The “Change Mantra' that produces Muhammadu Buhari as the Nigeria's democratically elected President in March 2015 has been one of the most popular slogan that penetrated every nooks and crannies of the country. It actually started with the President Buhari's campaign in 2011 when he contested under the platform of Congress for Progressive Change (CPC). Though he lost to the then incumbent President Goodluck Jonathan, the philosophy of change mantra resurfaces in 2015 under the All Progressive Congress the new political platform which Buharire-contested for Presidency of Nigeria and won. The idea of the Change Agenda may not be unconnected with his vision of how he wants to see Nigeria under his stewardship. (Chike. 2016), argued, one word, change, ignited a constellation of hopeful expectations among Nigerians who, for decades, had seen a mindless deterioration in every sector of their country. In another perspective, (Dele,2016), a political party, out of government, campaigning on the platform of "change" must as a minimum, address several questions: what is to be changed and why? How will it be changed and why? When the changes will occur? Who will undertake the change process? How much will it cost? What will be the benefit to the people of Nigeria?

But again, for the change agenda to be actualized one needs to ask whether at all, this change agenda is formally institutionalized under the Buhari's administration beyond how majority of Nigerians sees it as a mere campaign slogan of the APC?. Does it have content and time frame? what are the modus operendi on how it is going to be implemented? Is there any formal document that is presented to Nigerians as regard to the content of the change agenda? (Dele,2016) argued, "Change was a slogan devoid of content during the last election". The President himself enjoyed the full support of majority of Nigerians who saw him as solution to their sufferings. (Chike. 2015), argued, One source of hope, if not optimism, has been the president himself. He was perceived by many as sensitive to the suffering of the deprived Nigerians, morally earnest and a man who did not believed in ostentation.

One of the sectors promised to be reformed by the APC led administration of Muhammadu Buhari is the oil and gas sector. (Dauda 2015) argued, reform of the oil and gas sector is highly critical to the electoral expectations. The sector which remains critical to the Nigeria's survival has been under intense pressure characterized by corruption and mismanagement of the revenue accrued from the sector for over five decades. Again at the inception of the APC led government, the global oil crisis especially the drop in the prices of oil below $\$ 30$ per barrel has necessitated the administrations to take some painful measures aimed at strengthening the sector to respond to the global crisis. (Dauda. 2015) argued, in the face of threats posed by low oil prices, the government will need to look per beyond cosmetic reforms, if it is to meaningfully address the rot in the Nigeria's oil sector.

\section{Impacts of De-regulation in Ensuring Stability in the Nigeria's Downstream Oil Sector}

One of the impacts of oil de-regulation is that if fully implemented, it would help break the natural monopoly of the state owned enterprise by privatizing the state's owned refineries and removing the regime of price control. (Kurfi. 2016) argued, the natural government monopoly which creates instability in the downstream oil sector is as a result of its continued influence over the sector. Once the government allows private entrepreneurs to regulate prices and import the products at will, there is going to be stability in the sector within the shortest possible time both in terms of availability and affordability.

Deregulation promotes competition as oil marketers freely scouted for the product based on a fairly competitive price at the International market and sales to the final consumers at a price that is competitively affordable. (Kurfi. 2016) argued, Nigerians today are no longer talking about crises in the prices of diesel because importers are allow free hand to import the product and sales to the consumers at price determine by the cost of production. If government should stay away from regulating the price of petroleum product, the issue of long queues and constant scarcity of the product would soon be over because, importers are going to do everything possible to beat the competitive market demands.

Again, de-regulation help reduce the cost of government spending on subsidizing the sector which runs as high as \$1.5 billion dollars annually. These huge amounts can be re-directed towards meaningful capital development projects on sensitive sectors like education, health, agriculture, and holistic economic diversification. Deregulation would help government free more funds for local investment in the oil sector encourage foreign investment in the downstream infrastructure and stabilize market prices as competition increases. (George. 2014) summarized that, the new regime of de-regulation would help Nigerian government in addressing great in-balance between re-current and capital expenditure, reduced importation of refined products in to the country as more small and medium scales local refineries are going to be constructed.

(Ifiok. 2014), summarized that, deregulation would promote four cardinal reliefs to the Nigeria's oil and gas sector he pointed that, de-regulation promotes profitability, efficiency, un-employment and capital market development. On profitability he noted, this is likely to occur once the refineries are sold. Though the government may suffer losses from the sales of the refineries as some of them are going to be sold as scrap long term capital investment to maintaining the refineries have been saved. Efficiency he noted, occur normally after privatization as costs are reduced and redundant employees are retrenched. On the un-employment, he noted it cannot be avoided only that government should create "effective safety" nets so as to handle welfare matters. Finally the capital market development preferably $49 \%$ of the refined product after the final deregulation would be sold through the stock exchange. 


\section{Conclusion}

From the discussion so far it is very clear that, if Nigeria really wants to develop its economy through effective diversification and investment in infrastructure, private entrepreneurs have to be allowed to drive the nation's oil industry especially the downstream sub-sector so that, the atmosphere can allow for competition. And the best way to move the country from the present dilemma of corruption in the downstream oil sector is to deregulate and suspend payment of subsidy to allow the atmosphere give rooms for competitive economic development in the downstream sector of the petroleum industry as well as reserve money for infrastructural transformation of the country.

\section{References}

i. Aniefiok E. (2013), Petroleum Exploration and Production, Past and Present Environment Issues in the Nigeria's Niger Delta, (Online Version), American Journal of Environment Protection, retrieved from www. E-ISSN 1269 PP 78-79 Retrieved from www.researchgate.net 13th of April 2016.

ii. After Trillions Spent on Corrupt Fuel Subsidies, Federal Government Finally Bites the Bullet (2016), (Online Version) This Day News Paper, Retrieved From www.thisday.ngr.com 21 st of May 2016

iii. Adeleye A (2015), Deregulating the Downstream Sector of the Oil Industry, (Online Version), Vanguard News Paper, Retrieved from www.vanguardngr.org 22 $2^{\text {nd }}$ of May 2016

iv. Brendan G (2014), Why Fuel Subsidies in Developing Nations are an Economic Addiction, (Online Version) Bloomberg, Retrieved from www.blomberg.com 24th May 2016.

v. Donwa P. A, Mgbame C. O and Ogbude O. C (2015), Corruption in the Nigerian Oil and Gas Industry: an Implication for Economic Growth, (Online Version), International Journal of African and Asian Studiese-ISSN, 2409-6938 Vol. 14. Retrieved from www.ejournal.org/index 13th of May 2016.

vi. Ejoh E (2016) Fuel Price Hike: How Nigeria Wasted N10 Trillion on Subsidy, (Online Version) Vanguard News Paper, Retrieved from www.vanguardngr.org 23rd May 2016

vii. Gabriel E. (2011), Subsidy Removal: Nigeria to Face Grave Consequences If..., Lamido Sanusi, (Online Version),Vanguard News Paper, Retrieved from www.vanguardngr.com 30th of May 2016.

viii. Isiaka W. (2016), New Fuel Price Not About Subsidy Removal: FG, (Online Version),Daily Trust News PaperSunday, Retrieved From www.dailytrust.com, 24th of May 2016.

ix. Ifiok E (2012), The Economics of Privatizing and Deregulating the Downstream Oil Sector, (Online Version) Valore International Social Process Model Retrieved from www.ecojournal.org 22nd May 2016

x. Kurfi U (2016), Analysis on Petroleum Deregulation, Interview RFI, Hausa Service Monitored on the 11 th of May 2016.

xi. Kperogi F. (2016), Petroleum Price Hike: Time to Occupy Nigeria Again, (Online Version), Daily Trust Saturday, Retrieved From www.dailytrust.com 24th of May 2016

xii. Muideen O (2016), What led to Deregulation of Fuel Prices, (Online Version), Daily Trust News Paper Saturday, Retrieved from www.dailytrust.com 26 th of May 2016.

xiii. Micheal E. (2014), Subsidy Regime of Controversy, (Online Version), Vanguard News Paper, Retrieved From, www.vanguardngr.com 13 th of May 2016.

xiv. Olalekan W. A (2016), Not on this One Buhari, (Online Version) Daily Trust News Paper, Retrieved from www.dailytrust.com 21st of May 2016.

xv. Onyedi O. (2014), Oloiburi Versus Araromi? Where was Oil First Discovered, (Online Version), The Nation Newspaper, Retrieved from www.thenationonline.net on the 13th of April 2016.

xvi. Okafor A (2012), Effects of Fuel Subsidy Removal on the Nigerian Economy, (Online Version), Nigerian Technical Education and Entertainment Blog, Retrieved from $\quad$ www.cracksloaded.com 26 th of May 2016

xvii. Olufemi J (2015), Nigeria Lost Over N6.4 Trillion to Corruption Ridden Oil Sales (Online Version) NRGI Report. Retrieved from www.premiumstimesng.com 19th May 2016

xviii. Sekeumade A. B, (2009), The Effects of Petroleum Dependency on Agricultural Trade in Nigeria: An Error Correlation Modeling (ECM) Approach, (Online Version) Scientific Research Essay Vol 4(11) PP 1385-1391

xix. Dauda G. (2015), Nigeria's Oil Sector Reforms: An Agenda for the Buhari Administration, Online Version, Natural Resource Governance Institute, Retrieved from www.resourcegovernance.org on the 20th of June 2016.

xx. Chike F. M. (2016), Change Agenda in the Petroleum Sector, Online Version, The Guardian News Paper, Retrieved from www.allafrica.com on the $20^{\text {th }}$ of June 2016. 